\title{
Drainage Planning in the Cities of Bangladesh: Case Study of Drainage and Water Logging in Chaktai Commercial area, Chittagong
}

\author{
M. Ali Ashraf* \\ Md. Shariful Alam Chowdhury ${ }^{* *}$
}

\begin{abstract}
For quite some time, professional planning is being practiced in our cities. Unfortunately, drainage planning is the most neglected component of our city planning and management activities. Drainage engineering is done mostly on an ad hoc basis, often overtaking drainage planning. To understand the drainage problem of our cities, Chittagong in particular, Chaktai Commercial Area was identified as the case study area for further exploration and analysis. This case study examines the existing situation, assessing causes behind the problems, inquiring about the likings and disliking of the stakeholders, and identifying possible solutions as an essential input towards arriving at appropriate planning decisions. It identifies the guiding principles relating to the effective integration of a drainage network in the land use plan for the city. Considering physical characteristics, topography, catchment area and the routes of existing drainage channels, the urban area has been divided into 10 drainage areas. The Master plan sets out a staged development program of storm water, drainage and flood control works of the above drainage area up to the year 2015 to meet the Storm Water Drainage and Flood Control problems. Chaktai is the major seat of trade and commerce in Chittagong. It is observed that though Chaktai has lost its past glory as a national business centre controlling food business in the whole country, still it has retained its importance as a regional business hub and is continuing to contribute significantly to the national economy. The study thus helps us understand the nature, type and magnitude of the drainage and water logging problems faced by the city dwellers. The policy proposals and recommendations that are provided in the paper could be considered while preparing a land use plan for a city.
\end{abstract}

\section{Introduction}

Formal city planning in Bangladesh began with Sir Patrick Geddess producing a Master Plan for Dhaka in 1917. The plan was never implemented. With the establishment of a planning department in the erstwhile East Pakistan, now Bangladesh, in the year 1948, formal planning activities got an official beginning. A British consultant was engaged for producing the Master Plans for Dhaka, and Chittagong and Khulna was added later on. The Master Plans for Dhaka and Chittagong were produced in the year 1960 and 1961 respectively.

The plans produced were basically zoning maps with very little or no reference to drainage planning. Drainage planning was taken over by drainage engineering without any conscious endeavour to integrate drainage planning with the land use planning process. As a result engineers build drains, rehabilitated khals on the basis of actual situation in the catchments they serve. They did not give much recognition to the fact that the lands remaining a flood plain today would be filled and become a jungle of masonry or concrete buildings tomorrow. Very little provisions were made for flood storage. Architects and planners on the other hand, went ahead with their zoning proposals for housing and industries. They have allowed building in flood plains without providing for the appropriate drainage. Eye-catching layout plans for new residential areas and

\footnotetext{
M.Ali Ashraf is a professional engineer and town planner based in Chittagong. He is the current Chairman of the Bangladesh Institute of Planners, Chittagong Chapter

** Town Planner, Chittagong Development Authority (CDA), Chittagong, Bangladesh. Email: sharif@betsbed.com, payelbuet@yahoo.com
} 
satellite towns were produced where drainage was given a very little importance. While producing a drainage layout for a residential area, it is simply forgetten that these drains would be called upon to drain a much bigger hinterland during a rainstorm than the residential area itself. In the design of drains, there are inadequate and inappropriate sections.

No matter, whether the road width is 20 feet or 60 feet, the drain width mysteriously remained constant at 2 to 3 feet. We were very generous in building roads and highways but remained equally miser in building primary, secondary or tertiary drains of appropriate size. As a consequence, as expected, drainage became a menace for our cities. Last year, 1/3rd of the City of Chittagong went under water during the rainy season. There were areas where water remained stagnant for days together causing serious inconvenience and financial loss to the city dwellers. Unlike Dhaka, Chittagong with hills around could have ensured an efficient drainage system. But, very unfortunately, the city could not yet implement it.

To understand the drainage problem faced by our cities today and to arrive at some planning decisions towards formulating an efficient drainage plan to be implemented with the utilization of the best practices in drainage engineering, Chaktai Commercial Area has been identified as a case study on drainage and water logging problems. The research aims at identifying the guiding principles relating to the effective integration of a drainage network in the land use plans of Chittagong city. In doing so, the study aims at examining the existing situation, assessing cause behind the problems, inquiring about the likings and disliking of the stakeholders, and identifying possible solutions as an essential input towards arriving at appropriate planning decisions.

\section{Background Information: Chaktai Commercial Area}

Chaktai is the major seat of trade and commerce in Chittagong. It's a wholesale market dealing with food items like rice, pulse, onion, ginger, powder milk, sugar, edible oil, dry fish, etc., and building materials like C. I. Sheet, paint etc. Roads and lanes in Chaktai often remain congested because of trucks loading and unloading commodities to the roadside warehouses and yards. Retailers from greater Chittagong area frequently visit Chaktai for collecting their merchandise. Though Chaktai has lost its past glory as a national business centre controlling food business in the whole country, still it has retained its importance as a regional business hub and is continuing to contribute significantly to our national economy.

Business houses are moving out of Chaktai. Unlike in the past, Chaktai is losing its importance. It is failing to attract new businesses to the area because of certain problems. Drainage and water logging can be identified as one of the inter-related problems hindering development of Chaktai area. In fact, it is not a problem for Chaktai area alone, rather is the problem of the whole city of Chittagong. The drainage and water logging is a major problem that discourages development of Chittagong.

\section{Study Area}

The study has tried to identify an area where the main khals draining the city terminate. Additionally in socio-economic consideration, we have also tried to identify a densely populated commercially important area for the study. Chaktai commercial area fits into the above criteria. Both Chaktai and Rajakhali Khals, two main drainage channels of Chittagong, terminate in the river Karnaphuli traversing through this area. Part of the area is densely populated. Remaining part of the area is expected to be developed in the immediate future as the area falls within Bakalia, earmarked as a thrust area for development in the Structure Plan for Chittagong, 1995. For the sake of convenience, we have named the study area as Chaktai though the west bank of Chaktai khal, northern and eastern parts of the study area do not exactly fall within Chaktai. Incidentally, three different municipal wards namely: East Bakalia, South Bakalia and Baxirhat encompass the study area. Figures 1 and 2 present the boundary and location of study area respectively. The study area measures 58.68 hectares and is bounded on the east by Karnaphuli Bridge approach Road, on 
the west by Asadganj Road, on the north by Islam Foyez Road, Abu Zafar Road and Osman Ali Lane, and on the south by Karnaphuli River.

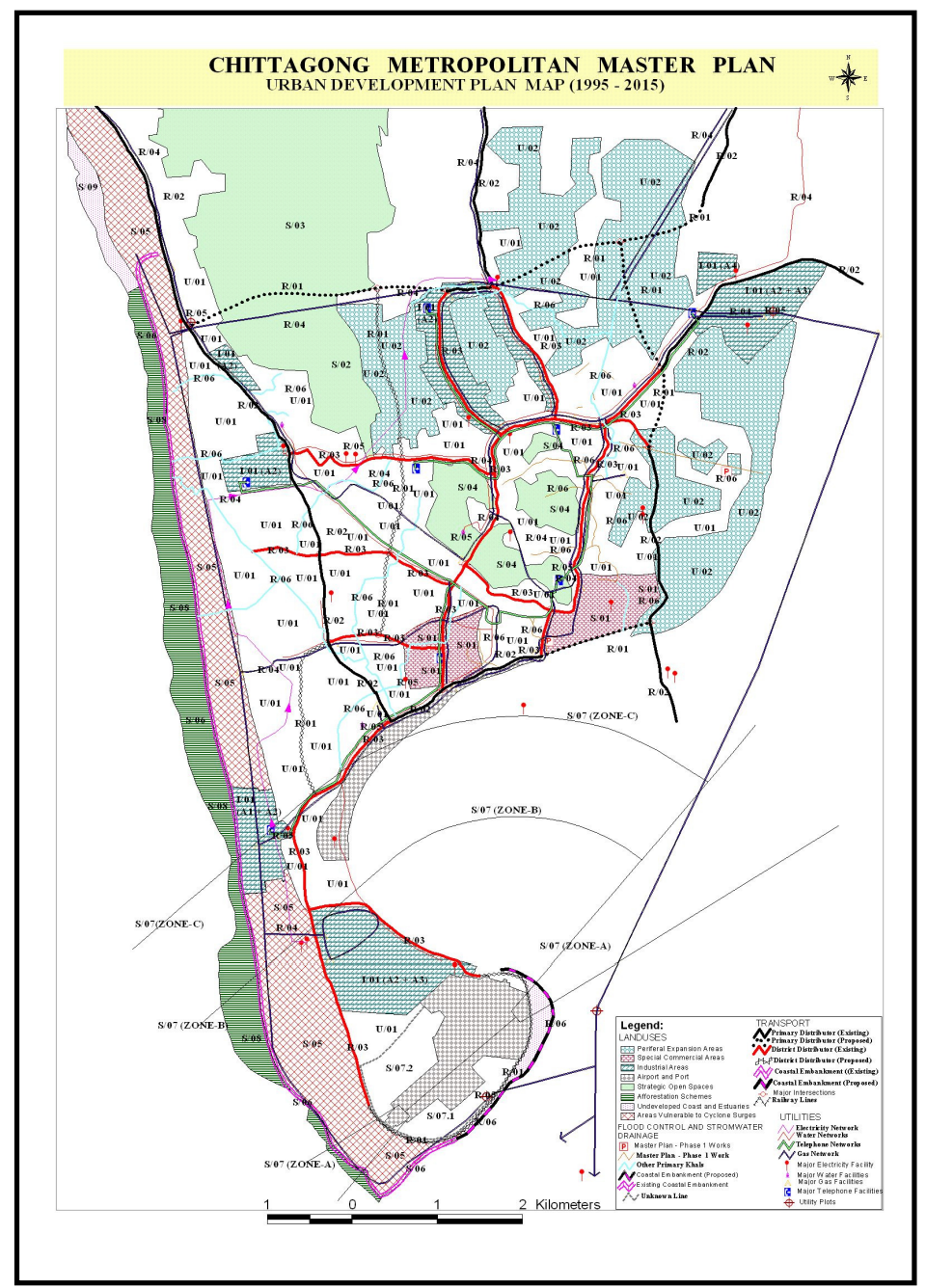

Fig. 1: Urban Development Plan Map (1995-2015), Chittagong Development Authority.

\section{Methodology}

To understand the drainage and waterlogging problem of the city as a whole and to arrive at a planning solution to alleviate the problem, the following methods were mainly utilized in completing the case study:

a) Reconnaissance Survey: physical verification

b) Questionnaire Survey

c) Interview with the stakeholders that includes residents, businessmen, ward commissioners etc.

d) Literature Survey: includes reviewing of published professional reports, newspaper reports on drainage and water logging with particular reference to Chaktai area.

e) Reviewing of Chittagong Storm Water and Drainage Master Plan, 1995 with particular reference to Chaktai area. 


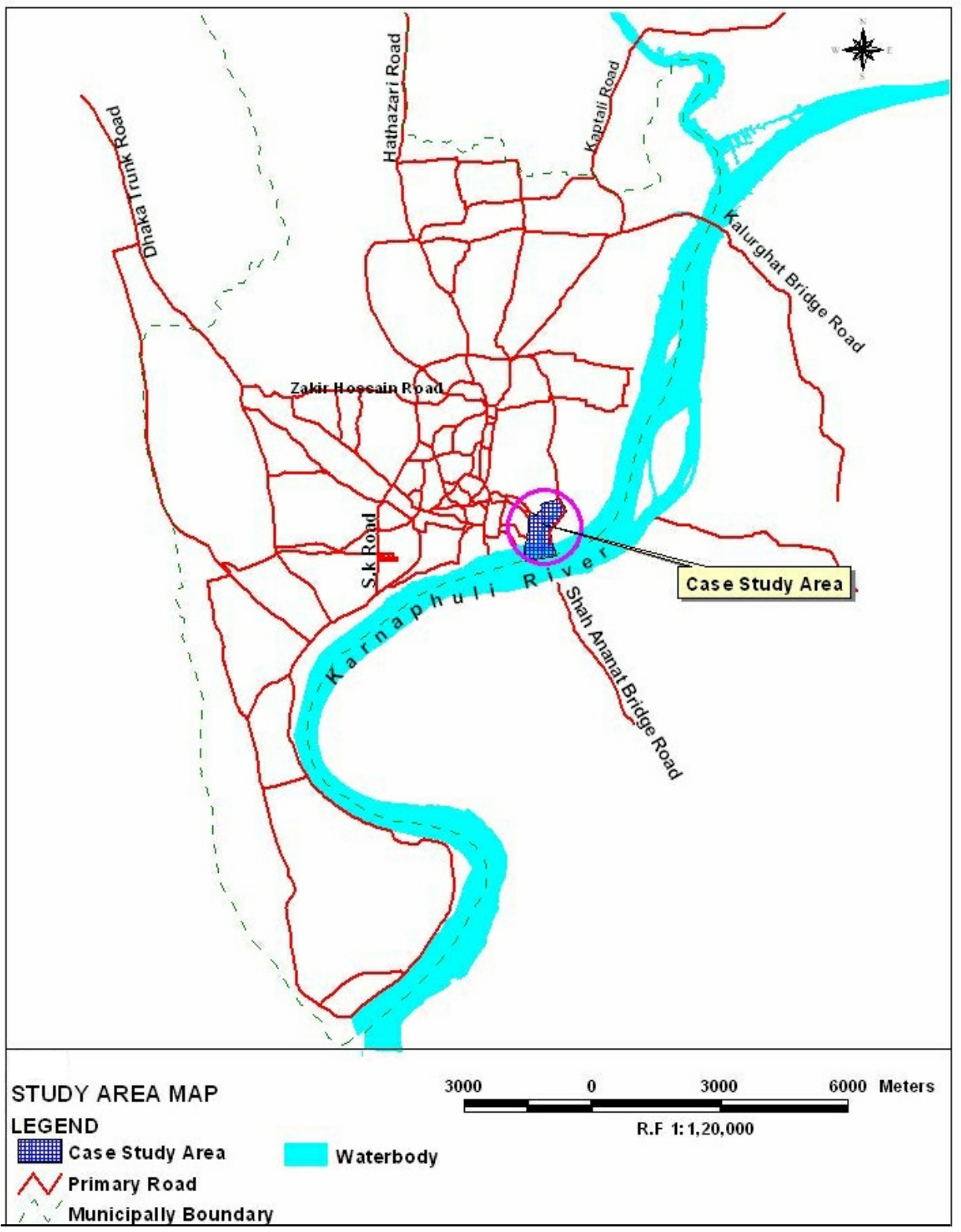

Fig. 2: Location of Chaktai commercial area (Study Area) in Chittagong City.

\section{Existing Conditions of Land Uses}

Existing land use pattern of the area is shown in Figure 3. Leaving aside the low-lying areas between Rajakhali Khal and the River Karnaphuli, rest of the area is densely built and heavily populated. Among the built-up area, pucca structure occupies $29.82 \%$, semi pucca-58.16\% and the rest $12.02 \%$ is kutcha structure. Low lying area between Rajakhali khal and the river Karnaphuli is about 14.49 hectares and occupies $24.69 \%$ of the study area. Built-up area is about $56.57 \%$ of the study area, and Khals and water bodies occupy the remaining $18.74 \%$ of the study area. Predominant land use types of the area are shown in Table 1. 
Table 1: Predominant land use types in the Study Area.

\begin{tabular}{|l|c|}
\hline Type of Use & \% of the Study Area \\
\hline Commercial & 18.75 \\
\hline Residential & 6.81 \\
\hline Mixed Use & 5.38 \\
\hline Industrial & 0.71 \\
\hline Agricultural/Low lying land & 24.69 \\
\hline Primary/Secondary khals & 17.24 \\
\hline Road Infrastructure & 7.29 \\
\hline Water bodies (ponds etc) & 1.5 \\
\hline Other uses & 17.63 \\
\hline Total & 100 \\
\hline
\end{tabular}

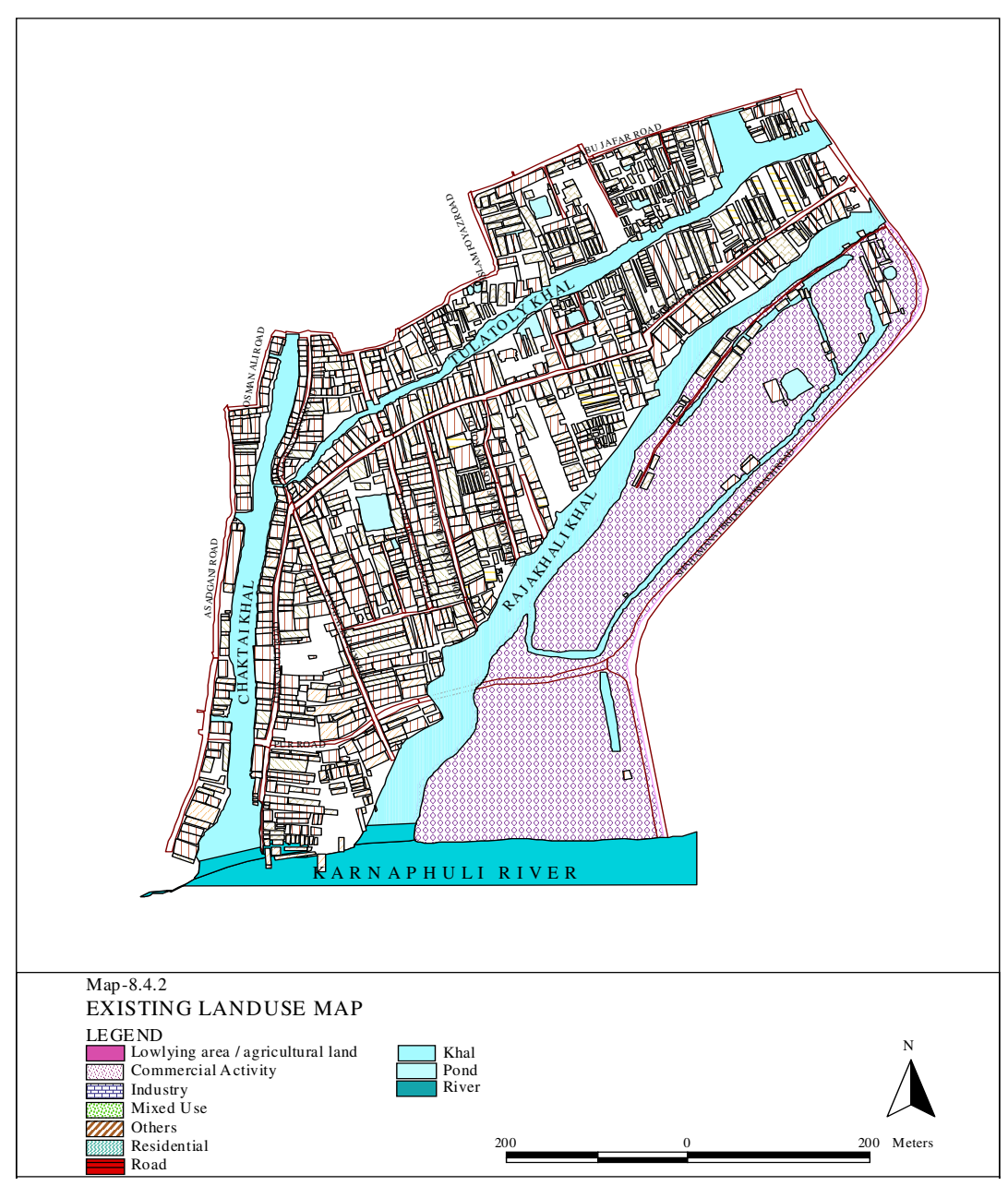

Fig. 3: Existing land use map of Chaktai commercial area. 


\section{Areas Vulnerable to Flood and Water Logging}

Figure 4 identifies the areas vulnerable to flood and water logging. Chaktai and Rajakhali Khals draining the city core passes through this area (Figure 4). Flooding takes place during monsoon and during high tides, especially during full moon and new moon. In majority of the flood prone areas, except very low lying marshy lands, flood or tidal water never remains stagnant for more than three hours. During monsoon, when areas like Shulakbahar, East Nasirabad, Mohammadpur etc. are inundated, and roads in those areas get temporarily converted to khal, roads in Chaktai area remain virtually free from floodwater. Peoples interviewed are of the opinion that inefficient storm water drainage network north of the Chaktai area are responsible for stagnation of flood water in those areas. Indiscriminate dumping of solid waste in drains was observed in some places causing stagnation of water.

Some photographs of the practical problems encountered by city dwellers in Chaktai commercial area of Chittagong shows the drainage problems and vulnerability of floods. Snapshots were taken of encroachments in Chaktai and Rajakhali Khal. Figures 5 and 6 illustrate encroachments in Chaktai and Rajakhali Khal areas respectively. Figures 7 and 8 show land grabbing and land filling respectively in Tulatoly Khal area. Figures 9 and 10 show indiscriminate dumping of solid waste and filling of a drain near Neamat Ali Bridge in Chaktai neighborhood. The problems observed in figures require immediate attention of the concerned authorities including the national government in order to keep the port city functional for the sake of national economy.

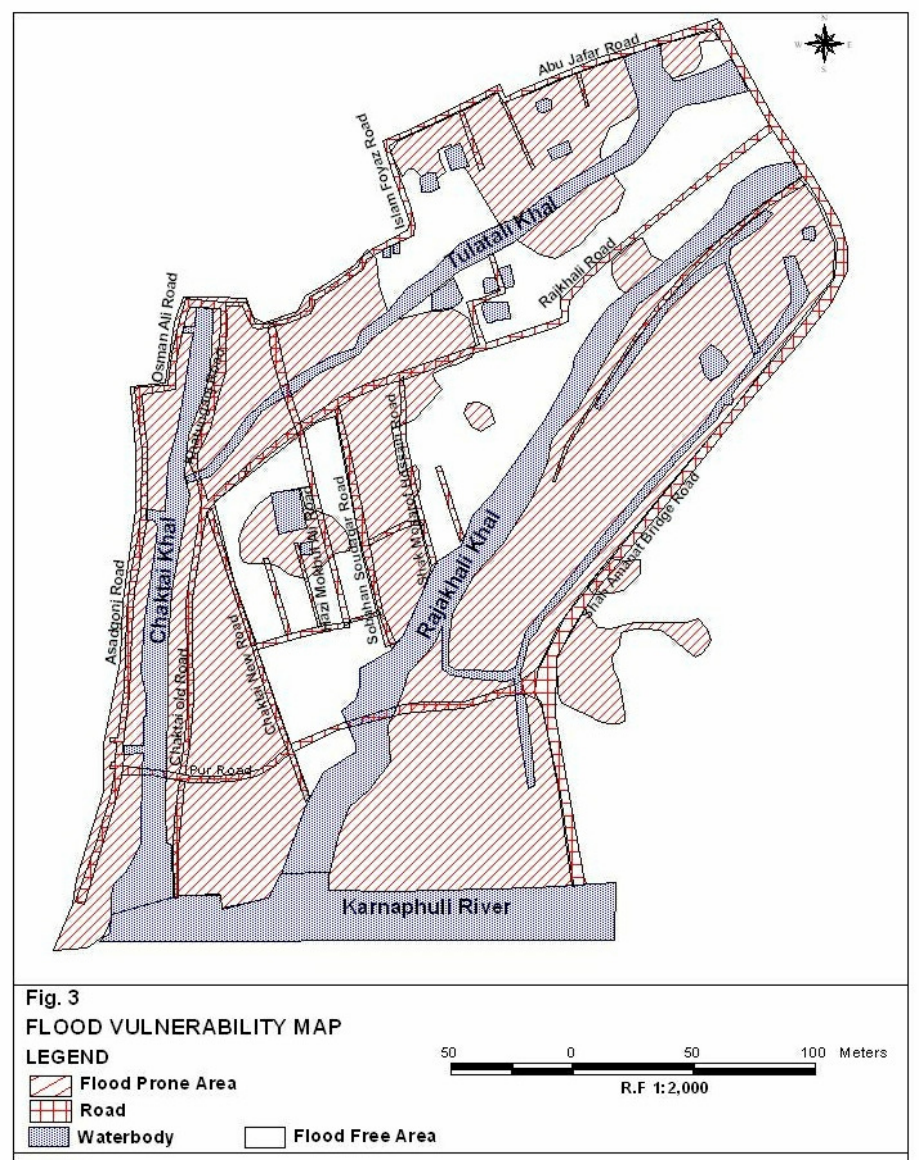

Fig. 4: Areas vulnerable to flooding in Chaktai commercial area. 


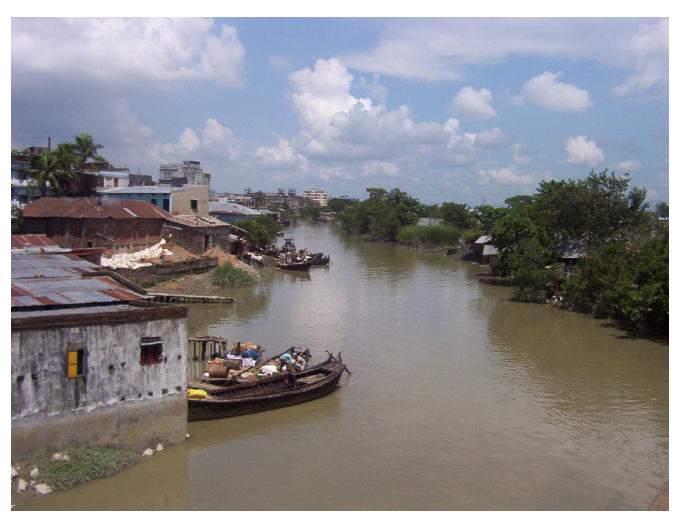

Fig. 5

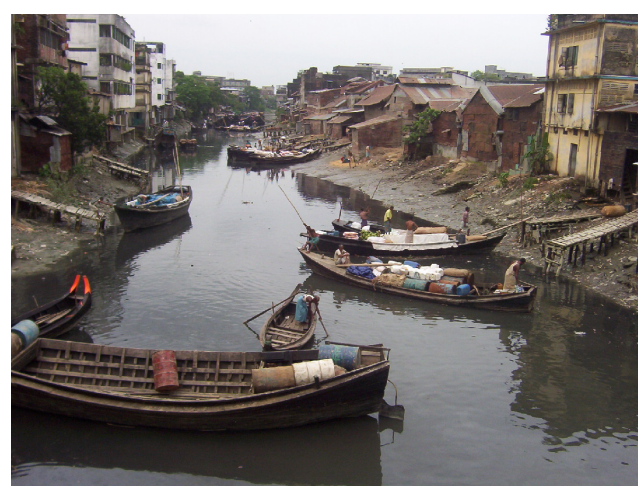

Fig. 7

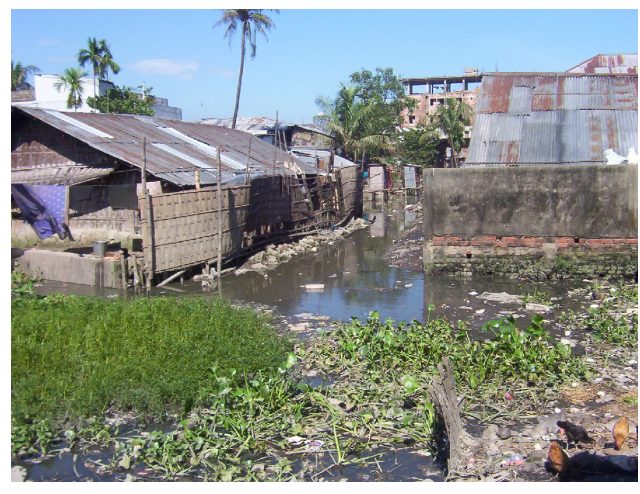

Fig. 9

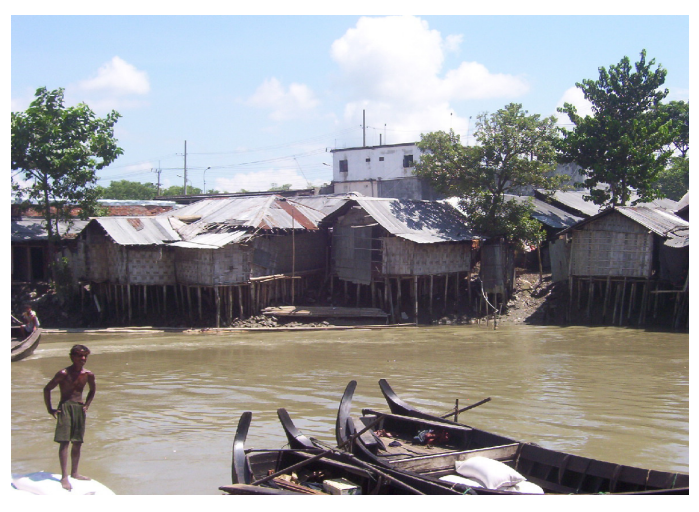

Fig. 6

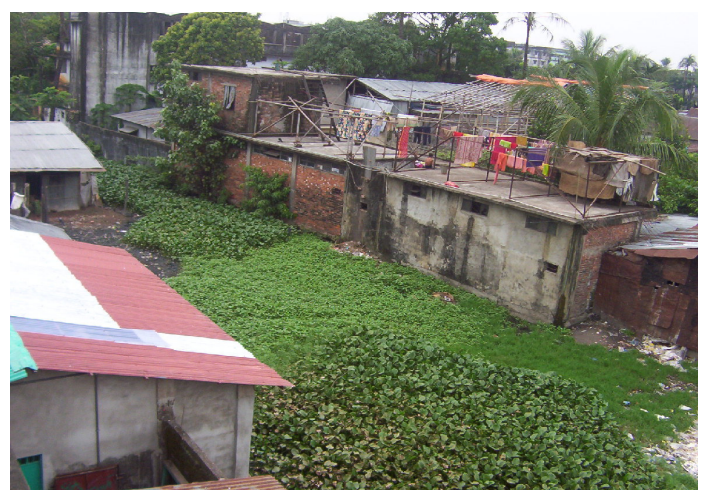

Fig. 8

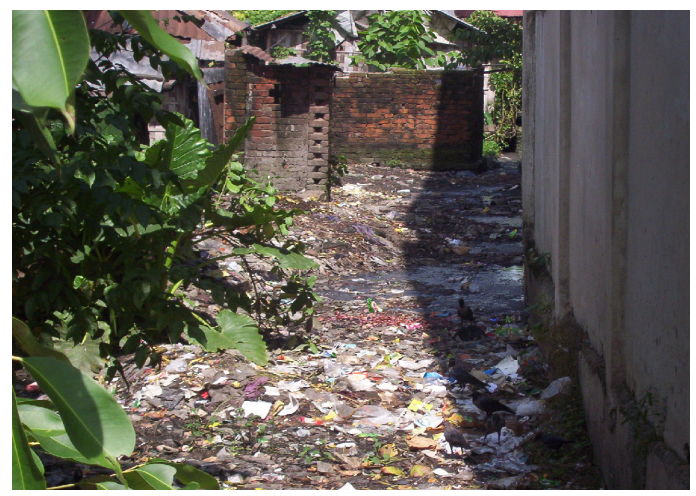

Fig. 10

\section{Survey Findings}

To find out the people's perception on drainage and water logging problem, a survey was conducted. For the purpose, a questionnaire was designed and field-tested. All endeavours were made to get the inputs from the stakeholders, like local residents and businessmen residing or working in Chaktai area. In total 21 respondents were randomly selected from the area. The questionnaires were served and their responses recorded. 
The survey gave a clear picture of the people's understanding of the flooding and waterlogging problem. However, on questions of reduction in property value and submergence of the area during heavy rainfall, it seems, people tried to be a little bit elusive in giving the right information. In areas occasionally inundated, people had a tendency to avoid mentioning it. A good number of respondents were not willing to accept a reduction in property value because of flooding and water logging in their area. They think, these incidences of occasional flooding will not reduce the property value there.

$45 \%$ of the respondents blamed inadequate storm water drainage as the cause of flooding and water logging in the area. Only $14.29 \%$ of the respondents were found living there for ten years and more. $52.38 \%$ people are living there for four to six years while $33 \%$ people are living even less; living for only 3 to 1 years. This indicates that long time businessmen, contrary to the popular belief, are not finding the area lucrative for doing business. The details of a few major findings are shown here:

Table 2: Responses from the respondents about various aspects

\begin{tabular}{|lr|}
\hline Aspects of enquiry & \% responses \\
\hline Level of Education & 19.05 \\
\hline Degree \& above: & 14.29 \\
H.S.C: & 09.52 \\
S.S.C.: & 38.10 \\
Primary: & 19.04 \\
Illiterate: & 66.679 \\
\hline Occupation of the respondents & 28.57 \\
\hline Business: & 04.76 \\
Service: & 14.29 \\
Student & 52.38 \\
\hline Duration of living in the area & 33.33 \\
\hline Above 10 years & \\
4 to 6 years & 31.60 \\
1 to 3 years & 00 \\
\hline Response to Specific Questions on Drainage and Water logging: \\
\hline How do you drain your holding? & 63.20 \\
Plot drain to primary drain / khal & 5.20 \\
Plot drain to secondary drain & 73.68 \\
Plot drain to tertiary drain & 15.79 \\
Plot drain to vacant plot & 10.53 \\
\hline Whether the sizes of drain are sufficient to carry rainwater in his area? \\
Drain size sufficient & \\
Drain size insufficient & 85.71 \\
No drain & 14.29 \\
\hline Whether there is backwater flow/flooding from khals in your area during tide? \\
Yes & 61.90 \\
No & 38.10 \\
\hline Whether water logging occurs during long duration high rainfall? \\
Yes & \\
No & \\
\hline
\end{tabular}




\begin{tabular}{|c|c|}
\hline \multicolumn{2}{|c|}{ What is the duration of submergence of main road in your area? } \\
\hline No submergence & 85.72 \\
\hline More that 2 hours submergence & $\mathrm{N}$ \\
\hline 1 to 2 hours submergence & 14.28 \\
\hline \multicolumn{2}{|c|}{ What is the duration of submergence of secondary road in your area? } \\
\hline No submergence & 66.67 \\
\hline More than 2 hours submergence & 19.04 \\
\hline 1 to 2 hours submergence & 14.28 \\
\hline \multicolumn{2}{|c|}{ What is the duration of submergence of Mohalla road in your area? } \\
\hline No submergence & 28.57 \\
\hline 1 to 2 hours submergence & 66.67 \\
\hline More than 2 hours submergence & 04.760 \\
\hline \multicolumn{2}{|c|}{ How many times per year flooding/water logging takes place in your area? } \\
\hline 10 times and above & 57.14 \\
\hline 7 to 9 times & 04.76 \\
\hline 4 to 6 times & 04.76 \\
\hline 1 to 3 times & 23.81 \\
\hline No Flooding & 09.53 \\
\hline \multicolumn{2}{|c|}{ How much area of your mohalla remains inundated for more than one hour? } \\
\hline No inundation & $23.81 \mathrm{~d}$ \\
\hline More than $30 \%$ inundation & 52.37 \\
\hline $21 \%$ to $30 \%$ inundation & 14.39 \\
\hline 0 to $10 \%$ inundation & 09.52 \\
\hline \multicolumn{2}{|c|}{ Did you notice any reduction in property value because of flooding and water logging? } \\
\hline No reduction in property value & 52.38 \\
\hline $5 \%$ to $20 \%$ reduction in property value & $28.57 \mathrm{~d}$ \\
\hline Above $20 \%$ reduction in property value & 19.05 \\
\hline \multicolumn{2}{|c|}{$\begin{array}{l}\text { What is the amount of loss per year to your property / commodity / shop etc. because of } \\
\text { flooding? }\end{array}$} \\
\hline No Loss & 52.38 \\
\hline Tk. O/- to $1,00,000 /-$ & 47.62 \\
\hline Tk. 1 Lac \& above & $\mathrm{NI}$ \\
\hline \multicolumn{2}{|c|}{ What in your opinion is the main cause of flooding and water logging in your area? } \\
\hline Inadequate storm water drainage & 45.00 \\
\hline Indiscriminate dumping of solid waste & $15.00 \$$ \\
\hline Tidal effect & 10.00 \\
\hline Combination of all above & 20.00 \\
\hline Not applicable to our area & 10.00 \\
\hline
\end{tabular}

\section{Recommendations on Storm Water Drainage and Flood Control in the Master Plan, 1995}

As part of the UNDP funded Chittagong Master Plan Project, a Storm Water Drainage and Flood Control Master Plan for Chittagong was prepared in the year 1994. The drainage master plan divided the city into twelve drainage zones and had specific proposals for these zones. The present study area Chaktai is located in the extreme eastern end of the drainage zones $5 \mathrm{a}$ and $5 \mathrm{~b}$ of the Drainage Master Plan. The following recommendations of the Drainage Master Plan are applicable to the study area. 


\section{Chaktai Khal:}

- Construction of abutment walls, lining of side slopes, re-profiling of the downstream end of the khal and bed lowering up to the river Karnaphuli were proposed for Chaktai Khal.

- A $21 \mathrm{~m}$ wide tidal regulator with the provision of a navigation gate at the mouth of Chaktai Khal was proposed.

- Rehabilitation of secondary khals flowing into the west of Chaktai Khal was proposed.

\section{Rajakhali Khal:}

- A $14 \mathrm{~m}$ wide tidal regulator at the mouth of Rajakhali Khal was proposed. It is further proposed that upstream end of the khal is to be blocked by an embankment.

- Local realignment and removing of obstructions to improve flow characteristics was proposed.

- Raising the level of 70ha land at the mouth of Rajakhali Khal was proposed to ensure sufficient freeboard in Rajakhali Khal.

\section{Rest of the area:}

- Pucca, kutcha, secondary and tertiary drains falling within the drainage zone $5 \mathrm{~b}$ are to be rehabilitated.

- In drainage zone 5a, in the high-density developed area, $20 \%$ of the tertiary drains are to be rehabilitated. In the medium density area, $30 \%$ of the tertiary drains are to be rehabilitated, and new tertiary drains are to be built in $20 \%$ of the drainage area, where no drains exist.

\section{Observations and Findings}

- At the base of the hills, at the confluence of tidal khals and on flat lands, because of sudden reduction in flow velocities, siltation is expected. It may not be possible to stop siltation completely, but measures can be adopted to reduce silt load in the khals and drains.

- Self cleaning channels and drains cannot be constructed throughout the city because of its topography. Therefore, de-silting of drains and khals at regular intervals is necessary.

- Chittagong does not have a reticulated sewer system. Khals and drains are being used as open sewer.

- During heavy rainfall, when floodwater flows over CDA Avenue, and in areas, like Shulakbahar, Mohammadpur, Chawkbazar etc. were under knee-deep water, but submergence of any main or secondary road in Chaktai was not observed. Excepting two to three isolated cases in a year, when heavy rainfall coincides with exceptional high tide, had there been provisions of adequate drainage upstream, the khals in Chaktai area along with a few new khals and the river Karnaphuli would be enough to drain the floodwater during monsoon.

- In the rainy season, some low lying flat areas in the city have small or no difference in the level of water with the adjacent khals and the river Karnaphuli during high tide; as such gravity drainage is difficult in these areas. Raising the low-lying lands by earth filling might be an option for development in these areas.

- The city has not adopted a drainage hierarchy. Irrespective of width of the road, sizes of drains remain almost similar everywhere. The most common drainage section observed in the area is $1^{\prime} \times 1.5$ '. Width of the tertiary drains generally varies between one foot and two feet. Depth of the drains varies between 1.5 foot and 2.5 feet. Primary, secondary and tertiary drains do not have any fixed dimensions. In most cases, natural khals having varying sections are used as primary drains. 


\section{Recommendations}

While recommending measures for alleviating the drainage problem in the city in general and Chaktai area in particular, guidelines of Chittagong Storm Water and Drainage Master Plan, 1995 were generally followed. A few new proposals, not recommended in the drainage master plan, are included. These proposals are not going to be a deviation from the basic concept and strategy of the drainage master plan. The policy proposals and recommendations are as follows:

- For improving local drainage, tertiary drainage network for all underdeveloped areas and proposed new developments are to be planned in advance, preferably following the road network. In the case of tertiary drains, attached to the mahalla lanes, a minimum drain width and depth of $1 \mathrm{ft} 6$ inches and 2 feet respectively are to be ensured. Depth will be variable depending on the topography of the site.

- Following road hierarchy proposed in the Chittagong Master Plan, 1995, there should be an approved drainage hierarchy. Provisions for drainage by the side of all primary and secondary roads are to be made mandatory. If the width of the drainage channel is correlated with the width of the road by a set rule, a lot of confusions can be avoided.

- A minimum width equivalent to $1 / 4^{\text {th }}$ of the road width is to be kept as drainage reserve on both the side of the road for providing primary and secondary drains. Following the aforementioned proposal, if the road has a width of $60 \mathrm{ft}$, then total drainage width by the side of the road will be a minimum of 15 feet, which means, 7.5 feet wide drain is to be provided on each side of the road. If necessary, covered drains can be used with the dual function of a drain and a footpath. There should be provisions for storm water access to these drains from the adjacent roads. Cleaning doors are to be provided at regular intervals. Implemention of the above proposal might become difficult in the existing densely developed areas. But, for all new developments, provisions for drains as proposed above can be made mandatory.

- Since we are aiming at gravity flow for drainage and because drainage network preferably will run parallel to the road network, topography and prevailing natural slopes of the area are to be taken into consideration, while deciding directional orientation of the proposed road networks in areas opened for new development. If this is done, drains running parallel to the roads will not face the risk of going against the natural slope.

- As mentioned earlier in observations and findings, open channels / khals are used as open sewer. We should aim at separating the domestic sewer from the storm sewers. A 20 feet wide service lane can be kept on both the side of the primary and secondary khals and at the initial stage, CDA can impose a moratorium on development on this stretch of land. Currently, all domestic sewers are linked with these khals. Interceptor sewer lines can be installed in these reserve lands. After installation of the sewer lines, this reserve land can also be used as a service lane / pedestrian road or as a green corridor facing the khals. Khals, once free from domestic sewer, will provide a recreational open space for the city dwellers. Some of these khals may even be used for passenger boat services.

- In the event of installation of underground sewer lines, sewer treatment plant near the mouth of these primary khals, with the aim of discharging treated effluents to the river Karnaphuli, will be required. Site selection and land allocation for the treatment plant will require planning clearance and decision.

- In the Drainage Master Plan 1995, a flood regulator was proposed in the mouth of Rajakhali Khal. Considering the importance of Rajakhali Khal as a navigation hub, a regulator with the provision of a navigation gate could be the best choice for development. 
- Dumping of solid waste in the drains is a behavioral problem commonly observed in the city. Massive awareness campaign is to be launched against dumping of waste in the drains. An incentive scheme, tagged with payment of municipal taxes, can be thought of encouraging people to keep their surrounding drains clean and waste free. Chittagong City Corporation (CCC) may offer a reduction (say 10\%) in holding tax to property owners with waste free surroundings.

- The aspect of implementation has to be taken seriously. The decision has to be made clearly on which authority will be appropriate for implementing the drainage master plan for Chittagong. As per mandate of the Chittagong Water and Sewerage Authority (CWASA) Ordinance, CWASA is responsible for providing storm water drainage and domestic sewers in Chittagong. But so far they have not done anything in this regard.

Traditionally, Chittagong City Corporation (CCC) is maintaining all the drains and khals in Chittagong. Under the Chittagong Municipal Services Sub-Project, CCC has constructed Box culvert under most of SK. Mujib Road resulting in the elimination of flooding of Sk. Mujib Road in Agrabad area. During the preparation of Drainage Master Plan for Chittagong in the years 1993 to 1995 , both CCC and CWASA provided valuable inputs. Hence either CCC or CWASA can take up the drainage master plan project for implementation. Currently, Chittagong Development Authority (CDA) is responsible for planning and development of Chittagong. We understand that CDA has submitted schemes to the government for implementation of the Drainage Master Plan, 1995. The policy proposals and recommendations made here, if accepted, can be incorporated in the Detail Area Plan for Chittagong.

\section{Conclusion}

Drainage Master Plan was approved officially by gazette notification in March 1999. Since then, ten years have elapsed and none of the phase-I projects of the Drainage Master Plan has been implemented. A strong political will and support is necessary for successful planning and implementation of any such plan. It is expected that this study will provide some useful thoughts for implementing the drainage master plan of Chittagong, and thus will help solve the drainage and water logging problems of the city. It is hoped that this paper will provide some useful ideas to the future researchers and policy makers on drainage design and planning at city scale.

\section{References}

Ashraf M.A. 2003. "Water logged City of Chittagong: problems, causes behind the problems \& their remedy", newspaper article in Bengali in Daily Azadi dated $26 \& 27^{\text {th }}$ July 2003.

Ashraf, M.A. 2000. Planned drainage \& flood control measures for Chittagong: what does Chittagong Storm Water \& Drainage Master Plan, 1994 say about it? Paper presented in a seminar on Chittagong Planned Urbanization, organized by Forum for Planned Chittagong on November 18, 2000 and published in the proceedings of the seminar.

Binnie \& Partners, Shankland \& Cox et.al, 1994. Sub-contractor for UNDP/UNCHS Project BGD 88/052, 1994

Chittagong Storm Water Drainage \& Flood Control Master Plan: Volume-2: Main Report

Daily Supravat Bangladesh (in Bengali), 2008. Reports on problems of Chittagong City Corporation (CCC) Wards: published as Ward Report Supplement. 